\title{
KETERAMPILAN TEKNOLOGI INFORMASI DAN KOMUNIKASI MAHASISWA PGPAUD UNIVERSITAS NEGERI PADANG
}

\author{
Syahrul Ismet ${ }^{1}$, Saridewi $^{2}$ \\ Jurusan PG PAUD, Fakultas Ilmu Pendidikan , Universitas Negeri Padang \\ Jurusan PG PAUD, Fakultas Ilmu Pendidikan , Universitas Negeri Padang \\ syahrul_unp@yahoo.com 08126760703
}

\begin{abstract}
ABSTRAK
Era Digital telah menggeser paradigma pembelajaran dari pola konvensional ke pola interaktif dan kreatif melalui pembelajaran berbasis Teknologi Komunikasi dan Komunikasi (TIK). Mata Kuliah TIK bagi mahasiswa Pendidikan Guru PAUD (PG-PAUD) di Fakultas Ilmu Pendidikan Universitas Negeri Padang diujukan menghasilkan berbagai keterampilan yang dapat membantu menyukseskan pembelajaran anak di era digital. Beberapa keterampilan yang telah dirasakan manfaatnya bagi mahasiswa PG-PAUD adalah: 1) keterampilan menggambar dan mewarnai; 2) Menghasilkan karya kreatif; 3) Memanfaatkan media sosial yang produktif dan positif; 4) Pembelajaran online; 5) Keterampilan literasi media.6) Keterampilan menganalisis game permainan anak usia dini.
\end{abstract}

Kata Kunci: Teknologi Informasi dan Komunikasi, Anak Usia Dini, Digital

PENDAHULUAN

Anak generasi abad ke-21 tumbuh dan berkmebang seiring dengan perkembangan pesat teknologi informasi dan komunikasi. Bahkan media TIK saat ini bukan lagi sebagai pelengkap kehidupan anak, namun menjadi kebutuhan yang sulit dipisahkan. Berbagai kajian pakar menunjukkan bahwa media TIK saat ini menjadi sarana sekaligus sumber belajar yang efektif dan menarik bagi anak.

Mahasiswa Jurusan Pendidikan Anak Usia Dini merupakan calon guru masa depan bagi anak di usia dini. Mereka menjadi bagian penting dalam melaksanakan berbagai stimulasi program pengembangan di lembaga pendidikan anak usia dini. Berbagai kompetensi dan keterampilan sebagai calon guru disiapkan bagi mereka, 
Syahrul Ismet, Saridewi. KETERAMPILAN TEKNOLOGI INFORMASI DAN KOMUNIKASI MAHASISWA PGPAUD UNIVERSITAS NEGERI PADANG. Early Childhood Vol. 3 No. 1, Mei 2019

termasuk penguasaan berbagai keterampilan TIK. Keterampilan yang diperoleh mahasiswa dalam proses perkuliahan TIK diharapkan bermanfaat nantinya dalam pengembangan pembelajaran di lembaga PAUD.

Keterampilan TIK bagi mahasiswa PAUD, menjadi bagian penting jika dihubungkan dengan kompetensi guru PAUD terhadap perkembangan anak pada era digital saat ini. George S. Morison (2004: 52) menegaskan, penggunaan teknologi komputer di rumah maupun di sekolah sangat baik untuk perkembangan anak usia dini. Anak sekarang merupakan generasi teknologi (digital age/digital citizen). Anak tumbuh dan berkembang dipengaruhi oleh melalui interaksi mereka dengan teknologi. Berbagai aplikasi permainan menarik dan menyenangkan bagi anak. Bahkan, bayi usia sembilan bulan saja sudah berinteraksi dengan komputer, saat duduk di pangkuan orang tuanya. Hal ini merupakan fakta penting bahwa anak-anak secara langsung sudah belajar dari komputer tersebut.

Menurut para ahli dalam Moore (2010:1), pemanfaatan komputer untuk anak usia dini, menumbuhkan sikap kritis dalam diri anak. Pada saat anak berinteraksi dengan komputer, anak akan mengamati, bermain dan mengembangkan kemampuannya tanpa batas. Anak berekplorasi sesuai keinginannya dengan mencoba berbagai pengalaman baru. Penelitian Critcher (2008), Drotner dan Livingston (2008), Hasebrink, Livingston, Haddon dan Olafsosson (2008, Linebarger dan Piotrowski (2009) menyimpulkan bahwa anak usia 3-5 tahun, saat ini mampu mengembangkan berbagai potensi mereka dengan belajar melalui media. Anak bisa langsung melakukan pengamatan, eksplorasi, bermain serta belajar melalui media digital yang mereka sukai.

Catherina dan Glenn de Padua (2010:1) juga menjelaskan beberapa keuntungan yang diperoleh anak dengan belajar komputer, yaitu: 1) meningkatkan keterampilan belajar anak, hal ini ditunjukkan berbagai hasil penelitian bahwa anak yang menggunakan komputer memiliki performa akademis lebih baik 2) menstimulasi kreativitas dan imajinasi anak, karena program komputer walau sederhana akan terasa menantang bagi anak, karena anak belajar mengidentifikasi masalah, menganalisa pilihan, dan memilih solusi terbaik, 3) meningkatkan perkembangan kepribadian, karena program komputer memungkinkan anak melakukan kesalahan, memperbaiki, dan mencoba lagi tanpa takut dimarahi. Anak menjadi terbiasa untuk berani mengambil risiko, memiliki sifat yang lebih independen, dan lebih percaya diri.

Mata Kuliah TIK yang dilaksanakan di Jurusan PGPAUD FIP 
Syahrul Ismet, Saridewi. KETERAMPILAN TEKNOLOGI INFORMASI DAN KOMUNIKASI MAHASISWA PGPAUD UNIVERSITAS NEGERI PADANG. Early Childhood Vol. 3 No. 1, Mei 2019

Universitas Negeri Padang termasuk dalam kelompok mata kuliah pengembangan, dengan bobot 3 SKS. Dosen pengampu mata kuliah menyesuaikan silabus dengan perkembangan kekinian yang selalu diupdate. Perubahan terasa lebih cepat ketika komputer mengalami perkembangan generasi dan munculnya berbagai aplikasi gadget dan android. Penataan materi perkuliahan yang disesuaikan dikemas dengan menarik dan membangun berbagai keterampilan.

Pembelajaran yang dilaksanakan memanfaatkan komputer berfungsi sebagai sarana yang membantu pencapaian tujuan pembelajaran. Banyak model penggunaan komputer dalam pembelajaran tersebut, salah satunya adalah pembelajaran berbasis komputer (PBK). Menurut Rusman, Dedi Kurniawan dan Cepi Riyana (2011: 98) PBK adalah: bentuk pembelajaran yang menempatkan komputer sebagai piranti sistem pembelajaan individual, dimana siswa berinteraksi langsung dengan sistem komputer yang sengaja dirancang atau dimanfaatkan oleh guru. Kontrol pebelajaran ini sepenuhnya ada di tangan siswa (student center), karena pembelajaran berbasis komputer merupakan pola pembelajaran bermedia, yaitu secara utuh sejak awal hingga akhir menggunakan piranti sistem komputer (CD interaktif).

\section{METODE PENELITIAN}

Peneilitan ini menggunakan metode penelitan deskriptif kualitatif. Penelitian ini bertujuan mendeskripsikan beberapa keterampilan TIK yang diperoleh oleh mahasiswa PAUD dalam perkuliahan di kelas dan online. Data diperoleh melalui observasi, best practice yang peneliti laksanakan serta didukung dengan dokumentasi dengan analisis model Milles and Hubberman.

\section{HASIL DAN PEMBAHASAN Temuan Penelitian}

\section{Keterampilan Menggambar dan Mewarnai (Paint)}

Keterampilan menggambar berbasis TIK merupakan program pengembangan seni (rupa) yang dapat diintegrasikan dengan berbagai program pengembangan lainnya, seperti kognitif (warna, konsep, sains), bahasa, nilai moral dan agama dan sosial emosional. Banyak tersedia berbagai aplikasi komputer yang dapat dimanfaatkan oleh mahasiswa atau guru yang sesuai dengan tujuan yang ingin dicapai. Menggambar dan mewarnai yang dilaksanakan mahasiswa menggunakan aplikasi paint. 
Fannisya Fany Fany Marita 1305206 ( 37 )

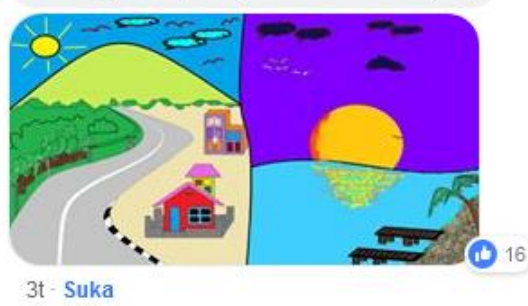

Gambar 1. Tema Alam

Safitriani Ulfa 51. Safitriani Ulfa (1300695)-12

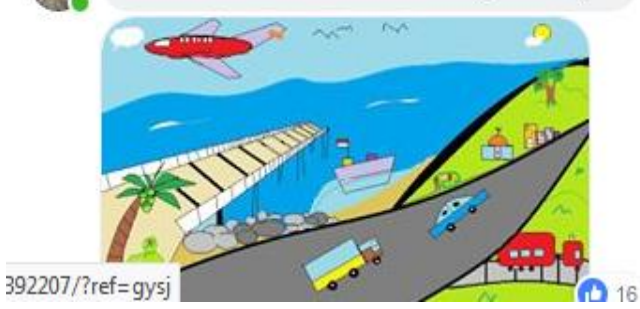

Gambar 2 Tema Angkutan

至

Agustin Lely Agustin Lely 50 . Agustin lely mergari (130

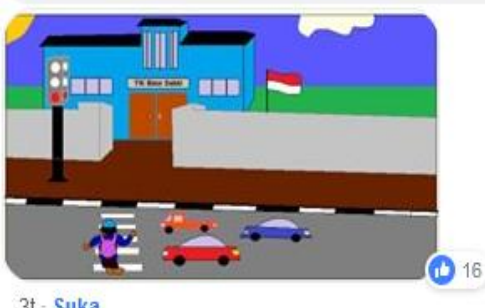

Gambar 3. Tema Lalu Lintas

\section{Menghasilkan Karya Kreatif (Movie Maker-Youtube)}

Mahasiswa diberi kesempatan praktek membuat video, menggunakan aplikasi movie maker. Ide video pembelajaran disesuaikan dengan topik anak usia dini yang diminati. Setelah video selesai dibuat, mahasiswa mengupload ke situs berbagi video (Youtube)
Dwi Lupita Sari 10. Dwi Lupita Sari_1300744 Judul : Pentingnya Peran Ayah. Link : https://www.youtube.com/watch?=-7/mrAGsvF04 Terima Kasih :-

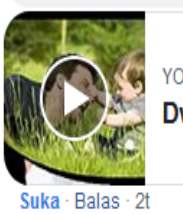

YOUTUBE.COM

Dwi Lupita Sari

Gambar 4. Video Tema Keluargaku

Dani Pratiwi 11. Dani Dwi Pratiwi - 1300732 - Judul: Yuk Kita Membuat Origami Ikan. Link: https://youtu.be/NNbZQqu_Odo thanks $\ddot{*}$

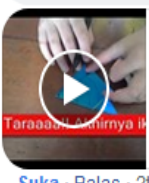

YOUTUBE.COM

Movie Maker Dani Dwi Pratiwi 13007322013 PGPAUD REG A

Gambar 5. Video Tema Motorik Halus

\section{Memanfaatkan Media Sosial} secara positif dan produktif

Mahasiswa mengiklankan video pembelajaran yang telah diupload ke situs Youtube melalui berbagai media sosial yang mereka miliki, seperti facebook, whatsapp dengan cara mengundang para pembaca/pemirsa untuk mengklik link, men-subscribed dan memberi komentar. Iklan dibuat melalui situs media sosial akun mahasiswa. 


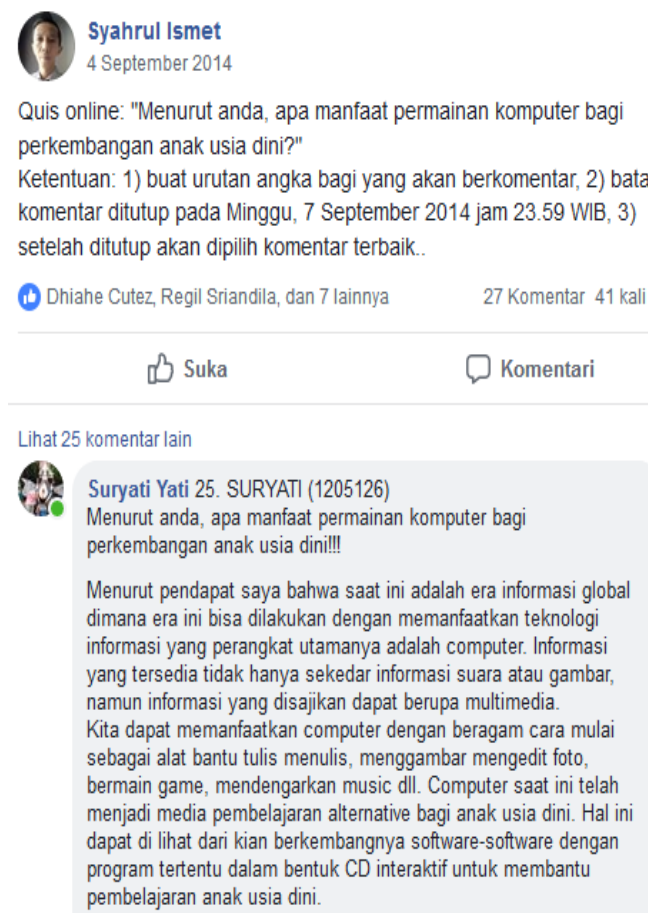

Gambar 6. Iklan di media sosial

\section{Pembelajaran online}

Aktivitas pembelajaran dapat dilaksanakan secara online, melalui berbagai fasilitas chatting online. Dosen memberikan arahan dan aturan yang jelas, sehingga dapat diberikan fedback dari mahasiswa. Chatting online ini dapat dikembangkan dalam bentuk kuis, diskusi group, dan sebagainya. Mahasiswa sangat berminat ketika pembelajaran dilaksanakan secara online ini.

\section{Keterampilan Literasi Media}

Mahasiswa dilatih memiliki keterampilan literasi media, yaitu memahami berbagai instruksi pembelajaran berbasis TIK serta mampu melaksanakan berbagai tugas dengan baik.

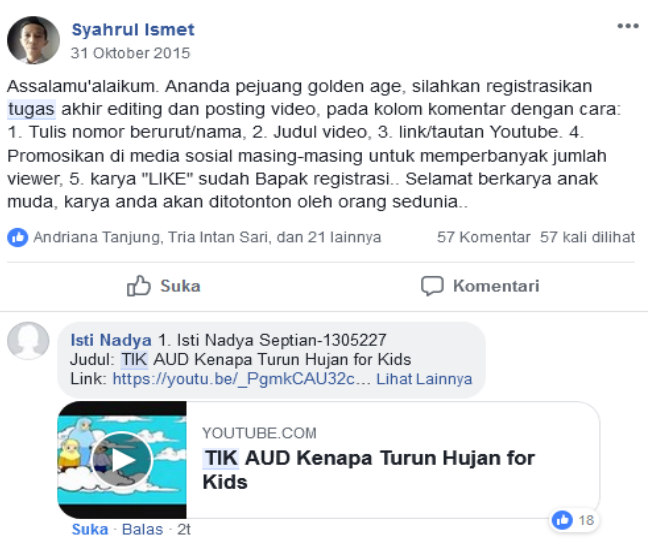

Gambar 8. Literasi Media

\section{Keterampilan Menganalisis} permainan anak usia dini

Perkembangan aplikasi permainan bagi anak yang sangat pesat saat ini memberikan dampak positif sekaligus dampak negatif bagi anak. Oleh karenanya, tidak semua aplikasi permainan yang layak dimainkan oleh anak. Mahasiswa PAUD diharapkan memiliki keterampilan melakukan analisis yang komprehensif untuk menilai kelayakan sebuah aplikasi games anak dengan konsep ilmu PAUD yang telah dipelajari. Keterampilan analisis dikembangkan melalui studi analisis, dibuat dalam bentuk file dan dikirim melalui e-mail. 
Syahrul Ismet, Saridewi. KETERAMPILAN TEKNOLOGI INFORMASI DAN KOMUNIKASI MAHASISWA PGPAUD UNIVERSITAS NEGERI PADANG. Early Childhood Vol. 3 No. 1, Mei 2019

PEMBAHASAN

Keterampilan Menggambar dan

Mewarnai . Menggambar dan mewarnai merupakan aktivitas bermain yang menyenangkan bagi mahasiswa dan anak. Banyak lingkup perkembangan yang dapat distimulasi secara terintegrasi melalui keterampilan menggambar dan mewarnai. Hal tersebut sesuai dengan Henniger seperti dikutip Morrison (2004:468) bahwa prinsip pengembangan permainan melalui komputer, yaitu: 1) bermain menunjukkan keaktifan anak, yang dapat meransang aktifitas pisik anak, 2) anak dapat memilih sendiri jenis permainan yang disukainya, 3) anak bisa bermain langsung, guru meminimalkan intervensi terhadap anak, 4) permainan berorientasi kepada proses, bukan karya yang dihasilkan anak, 5) permainan menstimulasi imajinasi dan kreatiftas anak, 6) permainan dengan resiko minim.

\section{Menghasilkan}

Karya

Kreativitas. Pemanfaatan komputer dalam dunia pendidikan anak, menurut Davidson dan Wright seperti dikutip Brewer (2007:125) didasari atas beberapa asumsi, yaitu: penggunaan komputer menjadi aktifitas sosial, penggunaan komputer didasari inisiasi anak dan pengalaman langsung, software komputer mendukung anak untuk bereksplorasi, bereksperimen dan menyelesaikan masalah, permainan komputer menawarkan hal-hal baru, dan komputer menjadi salah satu sarana mengembangkan berbagai keterampilan anak di dalam kelas.

\section{Menggunakan Media Sosial} secara positif dan produktif. Beragamnya media sosial saat ini membuat mahasiswa jauh dari perkembangan sosial. Padahal keterampilan komputer dapat membantu perkembangan sosial. Hal tersebut dikemukakan oleh Morrison (2008:116) dengan merinci banyak nilai sosial anak yang dapat dikembangkan melalui permainan komputer, antara lain pengendalian diri, kemandirian, kepercayaan diri, hubungan pertemanan yang positif, serta kemandirian beraktifitas tanpa selalu diawasi.

Pembelajaran online. Saat ini komputer bukan menjadi alat mewah, namun sarana belajar yang memiliki banyak keunggulan. Sesuai dengan penjelasan Ajen Dianawati (2009:1) bahwa fungsi komputer dapat membantu aktivitas pembelajaran siswa, sehingga dalam perkembangannya telah dimanfaatkan 
Syahrul Ismet, Saridewi. KETERAMPILAN TEKNOLOGI INFORMASI DAN KOMUNIKASI MAHASISWA PGPAUD UNIVERSITAS NEGERI PADANG. Early Childhood Vol. 3 No. 1, Mei 2019

sebagai alat untuk belajar di sekolah atau lembaga-lembaga bimbingan belajar. Bambang Warsita (2008: 140) menyatakan bahwa pemanfaatan komputer dapat meningkatkan prestasi hasil belajar dengan penggunaan waktu dan biaya yang relatif kecil.

\section{Keterampilan Menganalisis}

game permainan anak usia dini. Berbagai aplikasi yang tersedia saat ini tidak melalui proses selektif untuk bisa digunakan oleh anak. Sehingga butuh pendampingan dari orang dewasa ketika anak bermain dan butuh informasi dari para ahli terkait dampak yang dapat ditimbulkan oleh sebuah aplikasi permainan. Menurut Henniger (2013:471) terdapat tiga bentuk pendampingan orang tua dan guru ketika berinteraksi dengan anak dalam permainan komputer, yaitu sebagai instruktur, pembimbing dan model. Sebagai instruktur, guru dan orang tua membelajarkan bagaimana menggunakan teknologi. Sebagai pembimbing, guru dan orang tua membimbing anak dapat menyesuaikan diri, sehingga terampil menggunakan komputer. Sebagai model, guru dan orang tua akan selalu diperhatikan tentang cara menggunakan komputer yang baik.

\section{SIMPULAN}

Beberapa keterampilan TIK yang telah dirasakan manfaatnya bagi mahasiswa PG-PAUD FIP Universitas Negeri Padang adalah: 1) keterampilan menggambar dan mewarnai; 2) Menghasilkan karya kreatif; 3) Memanfaatkan media sosial yang produktif dan positif; 4) Pembelajaran online; 5) Keterampilan literasi media.6) Keterampilan menganalisis game permainan anak usia dini.

Keterampilan TIK bagi mahasiswa PG-PAUD FIP Universitas Negeri Padang bertujuan menyiapkan calon guru PAUD menghadapi tantangan globalisasi dan perkembangan teknologi informasi bagi anak di era digital.

\section{Saran}

Keterampilan TIK yang telah dirasakan manfaatnya bagi mahasiswa PG-PAUD FIP Universitas Negeri Padang merupakan best practise peneliti dalam mengampu, yang selalu mengalami perkembangan dan perubahan sesuai dengan tantangan kekinian.

Diperlukan perhatian para pakar dan praktisi terhadap perkembangan isu-isu pemanfaatan TIK dalam perkembangan anak saat ini, sehingga TIK bisa 
ditempatkan pada posisi yang bernilai positif bagi anak

\section{DAFTAR PUSTAKA}

Ajen Dianawati. 2009. Belajar Komputer Untuk Anak. Jakarta: Wahyu Media.

Jay Blanchard dan Terry Moore. 2010. The Digital World of Young Children: Impact on Emergent Literacy. T.tp:Arizona State University

Jo Ann Brewer. 2007. Introduction to Early Childhood Education. Boston: Pearson

Michael L. Henniger. 2013. Teaching Young Children. USA: Pearson: 2013.

Morrison, George S. 2004. Early Childhood Education Today. Colombus: Pearson

Morrison, George S.2008. Fundamentals of Early Childhood Education. Alih Bahasa Dasar-Dasar Pendidikan Anak Usia Dini oleh Suci Romadhona dan April Widiastuti. Jakarta: Indeks.

Rusman, Dedi Kurniawan dan Cepi Riyana. 2011. Pembelajaran Berbasis Teknologi dan Komunikasi. Jakarta: Rajawali Pers 